\title{
Reading Differently: Exploring "The Power OF THE REAL" IN LITERARY JOURNALISM
}

\author{
Lindsay MORTON ${ }^{1}$
}

\begin{abstract}
This paper contends that previous research on the experience of reading literary journalism has predominantly been focused on the experience of the ideal, implied and/or interpellated reader. Scholarly discussions about the qualitative differences between reading fiction and non-fiction are usually theoretical or based on close readings where the analyses are projected on to a generalised readership. However, recent developments in the fields of psychology, neuroscience, and cognitive narratology are opening avenues for qualitative and quantitative research into the experience of reading literary journalism. This article takes some tentative steps towards exploring the nature of "experientiality" for readers by asking questions of emerging research in order to further articulate the "power" of narrative non-fiction.
\end{abstract}

In the introduction to the landmark scholarly work The Literary Journalists, Norman Sims wrote: "Whether or not literary journalism equips me for living differently than other forms of literature, I read as if it might" (1984, p. 4). This comment is perhaps as interesting for its equivocation as its assertion; it speaks to the often-cited but nebulous "power" of non-fiction which distinguishes the reading experience from fiction. Decades later in 2018, Sims' fellow scholar

1 Lindsay Morton is an Associate Professor of English at Pacific Union College (California, United States).

Recherches en communication, $n^{\circ} 51$ - Article publié le 10/09/2020 
and founder of the International Association for Literary Journalism Studies (IALJS), John S. Bak, unequivocally states that "the reading experience of literary journalism differs from that of traditional journalism and of literature" and goes on to envision that by 2030, "literary journalism studies will have surely benefitted from new theories on how a reader of a New Yorker article... processes information differently from the reader of a story in, say, Le Monde...or in a historical novel" (2018, p. 31). Here Bak identifies a fertile ground for research. A recent review (Wu \& Gabrial, 2018, pp. 41-42) of the last eight years in the IALJS's flagship journal, Literary Journalism Studies, identifies 13 categories under which scholarly articles can be classified, including: the function of literary journalism; the field's historical development; the "reality boundary"; and the role of the journalist. While the reading experience of literary journalism is explored theoretically within these 13 categories, recent advances in disciplines such as neuroscience, cognitive narratology and narrative theory call for an interdisciplinary approach to reader responses as its own focus and field of research. To that end, this article responds to Bak's call to investigate the reader's experience with the primary research question: What are some qualitative differences between the experience of reading fiction and literary journalism? Using insights from a range of disciplines, I aim to make some tentative suggestions about how different approaches might illuminate how readers engage experientially with literary journalism, and better-articulate the "power of the real," which literary critic and author David Lodge claims gives narrative non-fiction "a compulsion that no fiction can quite equal" (The Art of Fiction 203).

Literary journalism's features recommend it as a dynamic and important field to explore the "power" of fiction and non-fiction respectively. Story-telling techniques such as a narrative arc, full scene reconstruction, focalization, dialogue in full, the use of symbol, extended metaphor, and first-person narration are routinely cited as characteristics of these "true-life stories that read like a novel or short story" (see also Connery, 1992; Hartsock, 2000, p. 22; Lounsberry, 1990; Sims, 1984). But the significance of the North American journalistic tradition dating back to the 1890s (Connery, 1990, p. 4; see also Hartsock, 2000, p. 16) is lost on many leading researchers investigating the experience of reading non-fiction. For example, prominent psychologists Raymond A. Mar and Keith Oatley, who frequently collaborate on research that explores the reading experience and its social effects (Mar et al., 2009, 2011; see Mar \& Oatley, 2008), differentiate between "bookworms"- 
or readers of fiction - and "nerds" — or readers of non-fiction — on the assumption that "non-fiction presumably does not sponsor the same simulation of the social world as narrative fiction" (Mar et al., 2006, p. 698). Distinguishing fiction from non-fiction in this way is complicated by an 'Author Recognition Test' that comprised part of the study, in which Bob Woodward and Norman Mailer-writers recognized for their use of storytelling techniques listed above (see Fuller, 1997, p. 150; Hersey, 1989, p. 267; Ricketson, 2014, p. 16)-were listed under non-fiction writers, demonstrably undermining the researchers' characterization of the genre. The researchers conclude that bookworms "may buffer themselves from the effects of reduced direct interpersonal contact by simulating the social experiences depicted in stories. Nerds, in contrast, by consuming predominantly non-narrative non-fiction, fail to simulate such experiences and may accrue a deficit in social skills as a result of removing themselves from the actual social world" (Mar et al., 2006, p. 705). Although carefully framed as provisional by the modal "may," these findings are arguably undermined by a distinction between fiction and non-fiction that is general at best, and at worst, misleading. Such studies highlight the importance of recognizing literary journalism as non-fiction, as I have argued elsewhere (Morton, 2013), and of pursuing a phenomenological investigation into the experience of reading literary journalism. While this article does not offer qualitative phenomenological data from readers of literary journalism, it does explore how findings from other disciplines might inform our understanding of what readers mean when they refer to the "power" of non-fiction narratives - but specifically, literary journalism.

John Hartsock's (2000, p. 42) often-cited claim that "narrative literary journalism's ambition is to engage the objectified Other" clearly frames the field as experiential in nature. The term "engage" signals an active process that may involve a combination of contact, connection, involvement or participation with the narrative, its subjects and issues on multiple levels for the reader, ranging from cognitive processing to political participation. "Experientiality" similarly denotes an active process - or more than one in the context of reading, according to Marco Caracciolo. In the context of both phenomenological approaches to literature and cognitive narrative theory, Caracciolo frames "experientiality" within two domains: as the textual representation of experience, and, as the readers' experiences of the narrative. Clearly these two domains are interdependent, but the distinction is useful to define "the situated, embodied quality of readers' engagement with stories" that 
is this article's focus (Caracciolo, 2014, p. 4). Caracciolo's approach emphasises interaction over representation as a way of conceptualising narrative, as he argues for a "'more-than-representationalist' position when it comes to theorizing story-driven experiences" (Caracciolo, 2014, p. 10). Indeed, some of the most promising advances in research on the effects of narrative on the reader are those in cognitive neuroscience which are just beginning to explore a range of effects of narrative elements on readers. But before surveying some interesting recent findings and their possible connection to literary journalism, it is important to take a brief look at some historical scholarship on this topic.

The effects of reading literary journalism have been a topic of much scholarly discussion from the 1970s onwards, but scholarship has primarily focused on the experience of the ideal, implied and/or interpellated reader. Scholars such as John Hollowell (1977), John Hellman (1981), Ronald Weber (1974, 1985), Barbara Foley (1986) and Phyllis Frus (1994) all made significant contributions to the theory and practice of literary journalism; each also makes claims about the experience of reading in abstracted and idealized ways. Typical of such claims, Hollowell implicitly posits an implied reader when analysing the work of Norman Mailer and Truman Capote, writing "In Cold Blood possesses a tremendous power to involve the reader. This immediacy, this spellbinding 'you-are-there' effect, comes less from the sensational facts... than from the 'active' techniques Capote employs" (n.p. ). Foley's Telling the Truth does important work defining the author-reader contract that again focuses on an ideal reader, while Weber claims that:

Nonfiction can touch the reader in ways fiction never can because of nonfiction's commitment to the truth of what can be known about the world. But fiction can touch us in ways nonfiction never can precisely because of fiction's commitment to the truth of what cannot be known about the world but only imagined - its commitment, in Forster's terms, to that "something beyond the evidence" we know is there. (1985, p. 46)

Weber's claims here echo those of Carey's on the "power" of reportage; but he is also similarly inarticulate about what constitutes the "ways" in which non-fiction can "touch" a reader.

This vagueness is again found in Daniel Lehman's Matters of Fact: Reading Nonfiction over the Edge (1997). The "edge" in the title 
is an acknowledgement that a non-fictional text contains entities and phenomena that "are ... available to and experienced by the reader outside the written artefact" (Lehman, 1997, p. 4). His project is thus to encourage readers to read "over the edge", either by going outside the text for external verification or by reading with the knowledge that this is a possibility. Accordingly, reading in this reflexive or critical manner will "implicate" the reader, producing an experience of reading that is anything but identical to reading fiction (Lehman, 1997, pp. 4, 32). Eric Heyne centres his critique of Lehman's work on both the notion of reading over the edge and the corollary inference of a fixed boundary between fiction and non-fiction. Heyne contends that Lehman's trope of reading "over the edge" is a metaphor, and thus a poor substitute for critical theory on the relationship between author, text, reader and subject (Heyne, 2001, p. 325). Perhaps ironically, Frus perhaps comes closest to offering a substantial account of literary journalism's power when arguing for the fictionality of all narrative forms. She writes:

Once the tension between nonfiction and fictional tendencies signaled by a given narrative has been resolved in favour of literature, the text becomes nonpropositional, and thus unlikely to be a factor in the politics of ordinary life, the domain of social experience and public expression where change is possible. (Frus, 1994, p. x)

In a roundabout way, Frus implies that literary journalism-when read as non-fiction - is propositional, thus likely "to be a factor in the politics of ordinary life, the domain of social experience and public expression where change is possible" (Frus, 1994, p. x).

Two decades later, there appear to be conflicting results in neuroscientific studies exploring the experience and processing of non-fiction and fictional narratives. In 'Fact vs. Fiction - how paratextual information shapes our reading processes' Altmann et al.'s 2014 study used 80 short narratives such as would be found in daily news, TV documentaries, novels, short- and crime stories, assigned with the paratextual markers: "real" or "invented." The study found specific, selective patterns of brain activation in participants who believed they were reading factual accounts of events (Altmann et al., 2014, p. 25). ${ }^{2}$ Stories from the same

2 The study states: "Reading stories on the assumption that they refer to real events, as reported in a newspaper or a magazine, selectively yielded an activation pattern 
bank, when labeled as fiction, engaged different activation patterns to those stimulated by non-fiction, including a region that "is involved in working memory, attention, action monitoring and pain perception. However, it also reacts sensitively to emotional valence and seems to play a role during the evaluation and representation of the value of future action" (Altmann et al., 2014, p. 26). ${ }^{3}$ The study draws on similar research to propose that "reading in a factual mode produces a stronger situational model than reading in a fictional mode" where textual information "needs to be integrated into the reader's world knowledge, being represented in autobiographical memory" (Altmann et al., 2014, p. 25). The key finding appears to be that readers cognitively process fiction and non-fiction differently: knowing whether a text is based on real-world subjects allows the text to re/structure schema that models "the real world." This is not to say that fiction cannot or does not affect the way readers see or understand the world; merely that non-fiction compels readers to consider and reassess their model of reality-this is Lehman's "implicated" reader - whereas with fiction, this is, at least theoretically, optional.

However, a 2017 study by Hartung et al. refutes Altmann et al.'s findings on the grounds that this and similar studies use "newspaper" vs. "literature" as labelling categories, and that "this manipulation does not only address factuality of the information, but likely is confounded with different genre and reading situation dependent contexts and reading goals" (Hartung et al., 2017, p. 12). While Altmann et al.'s study clearly used only "real" and "invented" labels for the narratives, it is important to note that the later study used literary texts presented as either fictional or factual, and found "no evidence that knowing that a story is based on true or fictional events affects reading behavior, experiential aspects of reading, or memory for events in the stories"

comprising the RSC, right TP, left MTG/STG, the ventral striatum, the premotor cortex and the cerebellum. The premotor cortex and the cerebellum which were more strongly activated in the facts condition than in the fiction condition are likely to be part of the mirror neuron system and involved in action observation ... imitation ... or imagination" (Altmann et al., 2014, p. 25).

3 The study states: "Reading stories on the assumption that they refer to fictional events such as those narrated in a novel, a short story or a crime story selectively engaged an activation pattern comprising the dACC, the right lateral FPC/DLPFC and left precuneus, which are part of the fronto-parietal control network (Smallwood et al., 2012) as well as the right IPL and $\mathrm{dPCC}$, which are related to the default mode network (Raichle et al., 2001)" (Altmann et al., 2014, p. 26). 
(Hartung et al., 2017, p. 12). Nevertheless, Hartung et al.'s findings do not appear to undermine Altmann et al.'s, as the criticism of the study's method is not accurate, and the 2017 study relied on self-reporting from subjects, while the 2014 study is based on fMRI scanning which unambiguously indicates stimulation of different neural pathways when reading fiction and non-fiction.

The extent to which paratextual cues influence readers' experience was also explored in a 2012 study, which found that story labels such as fiction and non-fiction influence transportation; that is, "an integrative melding of attention, imagery and feelings, focused on story events" (Green and Donahue quoted in Appel \& Malečkar, 2012, p. 460; see also Ryan, 2015, pp. 74-75). The researchers note: "Although nonfictional stories are expected to be less transportive in general (potentially due to previous experiences with news), they may lead to similar or at times even higher transportation scores than fiction, arguably due to the greater relevance of nonfictional incidents to recipients' real life" (Appel \& Malečkar, 2012, p. 474). This state may play into the "power" of non-fiction narratives - and literary journalism in particular-as it adds the element of surprise to the reader's experience. As reader expectations clearly play a role in experientiality, and surprise is one of the "core narrative affects" along with curiosity and suspense (Keen, 2015, p. 153), this outcome should not be unexpected. Marie Laure-Ryan would agree, but with a caveat. She proposes that there are four degrees of absorption in the act of reading: concentration, imaginative involvement, entrancement and addiction. The reader is a "split subject" who, when reading fiction, "is attentive both to the speech act of the narrator in the textual world and to the performance of the author in the real world", while the "split subject" reading non-fiction "engages emotionally and imaginatively in the represented situation but retains a critical attitude toward the accuracy of the report and rhetorical devices" (Ryan, 2001, p. 69), as will be discussed further below. The nature of the reader as "split" and "doubled" in some ways can account for the range of responses different people can have to the same narrative - or to readings of the same narrative at different times. Paul Armstrong observes that reading entails "a paradoxical duplication of subjectivities, an interplay of the "alien me" whose thought-patterns I recreate and inhabit, and the "real, virtual me" whose configurative powers of understanding cause this other world to take shape and, in the process, can find themselves transfigured and transformed" (Armstrong, 2018, p. 12). Given the "dynamic" nature of the reading expe- 
rience, Armstrong warns against facile connections between the experience of reading narrative and its real-world effects. After critiquing a range of neuroscientific studies claiming to have found connections between reading and empathy, he cautions:

Neuroscience cannot predict what the social consequences of narrative will be. The variabilities introduced by the "as if" of narrative representation and the "as" of doubling in reading are too many and too uncontrollable to permit simple, sweeping generalizations about the social powers of narrative. Anyone who claims that stories make us better people by enhancing empathy and theory of mind or that narratives inherently promote social progress should be met with considerable skepticism because such assertions oversimplify the complex, paradoxical interactions entailed in the exchange of stories. (2018, pp. 19-20)

Armstrong's point echoes cautions found in Suzanne Keen's Empathy and the Novel, which draws on fields as wide-ranging as narratology, moral philosophy, psychology, and neuroscience. Writing on the role of affect and empathy when reading fiction, a key point for Keen is that a reader's perception of a text's fictionality plays a role in subsequent empathetic response, by releasing readers from the obligations of self-protection through skepticism and suspicion (2007, p. 107). In other words, readers enter fictional worlds with a willing suspension of disbelief that allows them to feel a deep sense of empathy with characters, without subsequent demands to respond in a real-world or prosocial way. Keen again emphasizes that "fictional worlds provide safe zones for readers feeling empathy without experiencing a resultant demand on real-world action. This freedom from obligation," she writes, "paradoxically opens up the channels for both empathy and related moral affects such as sympathy, outrage, pity, righteous indignation, and (not to be underestimated) shared joy and satisfaction" (2011, pp. 88-89). A key question here for the experience of reading literary journalism is: might real-world subject matter preclude or obstruct empathic engagement? For Keen, the answer is yes. Given the protective barrier of fictionality is not at play, "the fact of others' perspectives and motivations activates our caution" (2007, p. 34). But a mitigating point is that the experiential state of "transportation" has been found to play a central role in the persuasive power of narrative. Literary journalism 
uses storytelling techniques strategically to immerse readers in a narrative situation similar to those found in fiction: first person narration, beginning in medias res, anachronic structure, dialogue in full, free indirect discourse or interior dialogue - each of which invite readers into immersion and empathic engagement, potentially disarming skepticism and suspicion. As scholars and practitioners alike have noted, the use of such techniques inviting a reader's immersion trigger ethical issues between literary journalists and readers (see Cowser, 2011; Ricketson, 2009). However, it is important to note that immersive techniques may work both for and against experiential engagement: for in that they may disarm skepticism and suspicion, and against in that - as Keen has observed - generic and formal choices made in crafting a narrative may invite or retard readers' empathic responses, depending on their disposition towards or against particular formulaic conventions (Keen, 2007, pp. XII-XIII).

Almost a decade later, Keen extended her research on narrative empathy and the novel to the study of non-fiction narratives; specifically, literary biography, autobiography, and memoir, again separating out life writing from reportage and "dry, factual informational texts" (Keen, 2016, p. 10). Keen does acknowledge "more affectively-charged narrative forms" including histories, but does not acknowledge journalism as a possible site for narrativity or experientiality - "the situated, embodied quality of readers' engagement with stories" (Caracciolo, 2014 , p. 4). For Keen, a key characteristic of narrativity is affect, a term which she reminds us elsewhere has Latin roots that emphasize its role in influencing action (Keen, 2015, p. 153). She writes: "Something has to happen in order to stimulate the unspooling of related events that constitute plot, and those changes of state invite readers to experience versions of affect" (Keen, 2015, p. 153), and notes that the core narrative affects of narrativity are curiosity, surprise and suspense. In this, she joins Monika Fludernik by downplaying the fiction/non-fiction distinction in favour of narrativity and narrative effects. Fludernik's lens is perhaps wider than Keen's as she distinguishes between non-fiction and narrative non-fiction without separating out life writing and, specifically, forms of journalism, preferring rather to define narrativity on the grounds of experientiality. Fludernik writes: "Narrativity...is a characteristic of entire texts and of genres, and it is constituted meta-generically in its basic function of experiential reappropriation. The model that I have presented...locates the notion of experientiality and narrativity on a level of basic-level cognitive meta-frames and meta-func- 
tions of human linguistic interaction" (2002, p. 318). Reorienting narrativity away from plot opens up investigation to literary journalism on the grounds of experientiality: narrative features such as full scene reconstruction, a guiding consciousness and emphasis on the subjectivity of the subject-characters, in addition to its real-world referentiality, should position literary journalism at the nexus of narratological investigation. Nevertheless, Keen writes: "Fludernik and I concur that the formal distinctiveness of fiction, theorized by Dorrit Cohn, is difficult to pin down - beyond the implicit existence of real-world referents. Yet real readers strongly feel that there is a difference between fictions about imaginary beings and narratives that offer factual accounts of real persons" (Keen, 2016, p. 15). Keen does not offer empirical evidence regarding narrative empathy and experientiality in non-fiction, but as a leader in the field, in broadening the scope of her enquiry Keen raises pertinent questions that will hopefully stimulate future research into the link between experientiality and empathy in literary journalism. Using Dave Eggers' What is the What (2006) as a jumping off point - a text that has previously been analysed for its literary journalistic features (see Vaessens, 2011)_Keen asks:

Does nonfiction that employs ambassadorial empathy for a contemporary purpose gain power in the historical moment of its publication?-do its readers actually act, taking steps to support the charitable organization promoted in the novel? Then, what happens as time passes? ...Do we read old life writing the same way that we read fiction-more empathetically because we can't be asked to act? Or does the real-world referentiality of new or recent life writing reinforce our empathetic and altruistic response? (2016, p. 21)

These questions offer important points of departure for future literary journalism scholarship grounded in empirical research to supplement existing research on the experience of reading literary journalism.

Of the existing scholarship on experientiality and the power of literary journalism, perhaps the most significant is John C. Hartsock's Literary Journalism and the Aesthetics of Experience (2014). A number of the topics above are raised and considered - albeit from different angles - but to conclude this paper I would like to summarize and extend some of Hartsock's key points that attend to the nature of 
"the power of the real." Building on the seminal work A History of American Literary Journalism: The Emergence of a Modern Narrative Form (2000), Hartsock rearticulates the aim of narrative literary journalism as "to engage in a revelation for the reader about our phenomenal world, one that is conjured imaginatively by means of sensate experience reflected in language" $(2014$, p. 4). This language may at first appear jarring in a study of a form of journalism, but Hartsock repeats and deepens assertions that the engagement of the imagination is critical to the creation of meaning. He writes: "to get the public to participate is to better engage their subjectivities and elicit an empathic response.... Telling traditional stories imaginatively engages the reader's consciousness in sorting through the complexities of community problems" (2014, p. 23). Of course, as we have seen, and as Hartsock acknowledges, apprehending the phenomenal world whether in person or through narrative has "implications far beyond a seemingly simple and uncomplex referentiality" (2014, p. 26). To return to the "split" reader, Keen, Ryan and Armstrong all concur that reading non-fiction entails a push-and-pull experience of engagement and resistance: the text invites immersion while the reader is compelled by paratextual features to read with a critical eye on representation of the phenomenal world. While this "split" feature may seem prohibitive for immersion in the literary journalistic narrative, I propose it is in fact this tension that in part produces the nebulous "power" of the reading experience. To read fiction is to give oneself over to the narrative; but to resist the narrative while engaging in it experientiality through vivid scenes, finely wrought characterization, dialogue in full and sensory detail is to deepen the feel of its authenticity when its particulars are verified. For the critical reader, this "power" might be articulated as the reader's drive to overcome the necessary suspension of belief, rather than the willing suspension of disbelief as in the reading experience of fiction.

Playing into this reading experience of "doubleness"- a sensibility that is willing to engage while remaining at a safely skeptical distance - is the element of surprise, also mentioned earlier. As demonstrated a the range of studies by leading researchers such as Mar and Oatley (2006), Keen (2016), Hartung et al. (2017), and by the absence of any reference to literary non-fiction in the literature, non-fiction can be conceived of in a narrow and unrepresentative way, which prepares readers with particular reading strategies that are far less demanding than those evoked by literary journalism. In addition, the paratextual cue "non-fiction" usually primes readers for informational and/or expo- 
sitional prose, setting low expectations for narrative transport (Appel \& Malečkar, 2012), whereas Hartsock claims "narrative engages us in a degree of psychological transport that the inverted pyramid and conventional feature stories cannot equal" (2014, pp. 22-23). Indeed, a feature of literary journalism is the invitation to narrative immersion through an opening passage that challenges generic expectations, as exemplified in Rebecca Skloot's The Immortal Life of Henrietta Lacks:

There's a photo on my wall of a woman I've never met, its left corner torn and patched together with tape. She looks straight into the camera and smiles, hands on hips, dress suit neatly pressed, lips painted deep red. It's the late 1940s and she hasn't yet reached the age of thirty. Her light brown skin is smooth, her eyes still young and playful, oblivious to the tumor growing inside her-a tumor that would leave her five children motherless and change the future of medicine.

Of course, the element of surprise will not be a factor for all readers, particularly followers and scholars of literary journalism. But the third and final element to be raised here will arguably be a powerful shaping factor for all readers.

As indicated earlier, real-world referents as represented in literary journalism stimulate a different network of neural pathways to those stimulated by reading fiction. Whether through expectations set by genre or a more general - and simplistic - expectation of fact v. fictionality, readers are indeed implicated by the nature of literary journalism's truth claims. A much-cited study from 1994 found that "reading in a factual mode resulted in a stronger situation model than reading in a fictional mode" (Zwaan as cited in Altmann et al., 2014); that is, readers recognize the inevitable relevance of non-fiction to their world knowledge, therefore non-fiction has not only the power to literally change someone's mind, but also the authority. Of course, that claim must be modified: leading narratologist Gerard Genette indicates that the illocutionary power a paratext is potential rather than given, although he clearly sees authorial intention as valuable. He states that "valid or not, the author's viewpoint is part of the paratextual performance, sustains it, inspires it, anchors it," but that "the critic [or the reader] is by no means bound to subscribe to that viewpoint. I maintain only that, knowing it, he cannot completely disregard it, and if he wants 
to contradict it he must first assimilate it. ... To accept [the paratext]or, for that matter, to reject it - one is better off perceiving it fully and clearly" (Genette, 1997, pp. 408-409). Of course, much literary journalism has very specific truth claims, and Hartsock points out that there are inevitable existential consequences to disregarding these:

In acknowledging that the existential consequences could apply to us in our phenomenal world, as opposed to the allegorical reflected in the purely fictional, we cannot afford, in an act of denial, to turn our backs - physical, emotional, psychic, spiritual, or whatever combinationon the differentiating qualities inherent in the phenomenal. (Hartsock, 2014, p. 33)

We might add 'legal' to the consequences of denying "the way things are", as cases such as Janet Malcolm's and Jeffrey Masson's 10 -year defamation stand-off demonstrated. Given this impulse to restructure the workings of our schema, Hartsock observes that literary journalism may result in "cognitive disruption or estrangement" from our understanding of the world as it is: "The blinders of our idealizations or totalizations have been removed - or at least diminishedand we detect the phenomenal world anew as well as our place in it" (2014, p. 35). While this is perhaps an idealization in itself, the point is sound: literary journalism inheres in its truth claims an obligation to see the world differently; whereas fiction releases us from this obligation through its "protective barrier of fictionality" (Keen, 2007, p. 34).

This paper set out to explore the nature of "the power of the real" by asking: what are the qualitative differences between the experience of reading fiction and literary journalism? Research is still developing and producing conflicting evidence in a range of disciplines. However, I have tentatively offered some suggestions accounting for the "power" of reading literary journalism, which include the tension produced by a "split" reading; the drive to overcome a necessary suspension of belief; the element of surprise in its literary nature; and its authority to restructure our understanding of "how the world really is." Leaning on the scholarship of Hartsock and others, I offer these suggestions to add to the discussion of what sets literary journalism apart from other forms of media - both fiction and non-fiction - in hopes that it will position literary journalism scholarship on experientiality as a new frontier for neuroscientific, cognitive and aesthetic narrative studies. 


\section{References}

Altmann, U., Bohrn, I. C., Lubrich, O., Menninghaus, W. \& Jacobs, A. M. (2014). Fact vs fiction-How paratextual information shapes our reading processes. Social Cognitive and Affective Neuroscience 9(1), 22-29. https://doi.org/10.1093/scan/nss098

Appel, M. \& Malečkar, B. (2012). The Influence of Paratext on Narrative Persuasion: Fact, Fiction, or Fake? Human Communication Research 38(4), 459-484. https:// doi.org/10.1111/j.1468-2958.2012.01432.x

Armstrong, P. B. (2018). Neuroscience and the Social Powers of Narrative: How Stories Configure Our Brains. English Language and Literature 64(1), 3-24.

Bak, J. S. (2018). "The Past, the Present and the Perhaps" of LJS and the IALJS. Literary Journalism Studies 10(2), 23-33.

Caracciolo, M. (2014). The Experientiality of Narrative: An Enactivist Approach. Walter de Gruyter \& Co.

Connery, T. B. (1990). A Third Way to Tell the Story: American Literary Journalism at the Turn of the Century. In N. Sims (Ed.), Literary Journalism in the Twentieth Century (pp. 3-20). Oxford University Press.

Connery, T. B. (Ed.). (1992). A Sourcebook of American Literary Journalism: Representative Writers in an Emerging Genre. Greenwood Press.

Cowser, B. (2011). What We Said of It Becomes a Part of What It Is: Rendering Real Places. River Teeth: A Journal of Nonfiction Narrative 12(2), 109-122.

Fludernik, M. (2002). Towards a "Natural" Narratology. Routledge.

Foley, B. (1986). Telling the Truth: The Theory and Practice of Documentary Fiction. Cornell University Press.

Frus, P. (1994). The Politics and Poetics of Journalistic Narrative: The Timely and the Timeless. Cambridge University Press.

Fuller, J. (1997). News Values: Ideas for an Information Age. University Of Chicago Press.

Genette, G. (1997). Paratexts: Thresholds of Interpretation. Cambridge University Press.

Hartsock, J. C. (2000). A History of American Literary Journalism: The Emergence of a Modern Narrative Form. University of Massachusetts Press.

Hartsock, J. C. (2014). Literary Journalism and the Aesthetics of Experience. University of Massachusetts Press. http://ebookcentral.proquest.com/lib/slq/detail.action?docID $=4744413$

Hartung, F., Withers, P., Hagoort, P. \& Willems, R. M. (2017). When Fiction Is Just as Real as Fact: No Differences in Reading Behavior between Stories Believed to be Based on True or Fictional Events. Frontiers in Psychology, 8. https://doi. org/10.3389/fpsyg.2017.01618

Hellmann, J. (1981). Fables of Fact: New Journalism as New Fiction. University of Illinois Press.

Hersey, J. (1989). The Legend on the License. In Killing the Messenger: 100 Years of Media Criticism (pp. 247-267). Columbia University Press.

Heyne, E. (2001). Where Fiction Meets Nonfiction: Mapping a Rough Terrain. Narrative 9(3), 322-333.

Hollowell, J. (1977). Fact and Fiction: The New Journalism and the Nonfiction Novel. University of North Carolina Press. 
Keen, S. (2007). Empathy and the Novel. Oxford University Press.

Keen, S. (2011). Introduction: Narrative and the emotions. Poetics Today 32(1), 1-53.

Keen, S. (2015). Narrative form (Second edition). Palgrave Macmillan.

Keen, S. (2016). Life Writing and the Empathetic Circle. Concentric: Literary and Cultural Studies 42(2), 9-26. https://doi.org/10.6240/concentric.lit.2016.42.2.02

Lehman, D. (1997). Matters of Fact: Reading Nonfiction over the Edge. Ohio State University Press.

Lounsberry, B. (1990). The Art of Fact: Contemporary Artists of Nonfiction. Greenwood Press.

Mar, R. A. \& Oatley, K. (2008). The Function of Fiction is the Abstraction and Simulation of Social Experience. Perspectives on Psychological Science 3(3), 173-192. https://doi.org/10.1111/j.1745-6924.2008.00073.x

Mar, R. A., Oatley, K., Djikic, M. \& Mullin, J. (2011). Emotion and narrative fiction: Interactive influences before, during, and after reading. Cognition \& Emotion 25(5), 818-833. https://doi.org/10.1080/02699931.2010.515151

Mar, R. A., Oatley, K., Hirsh, J., dela Paz, J. \& Peterson, J. B. (2006). Bookworms versus nerds: Exposure to fiction versus non-fiction, divergent associations with social ability, and the simulation of fictional social worlds. Journal of Research in Personality 40(5), 694-712. https://doi.org/10.1016/j.jrp.2005.08.002

Mar, R. A., Oatley, K. \& Peterson, J. B. (2009). Exploring the link between reading fiction and empathy: Ruling out individual differences and examining outcomes. Communications 34(4). https://doi.org/10.1515/COMM.2009.025

Morton, L. J. (2013). Epistemic Responsibility and the Literary Journalist [Unpublished Thesis]. Avondale University College.

Ricketson, M. (2009). Ethical Issues in the Practice of Book-Length Journalism [Unpublished Thesis]. Monash University.

Ricketson, M. (2014). Telling True Stories: Navigating the challenges of writing narrative non-fiction. Allen \& Unwin.

Ryan, M.-L. (2001). Narrative as Virtual Reality: Immersion and Interactivity in Literature and Electronic Media. Johns Hopkins University Press.

Ryan, M.-L. (2015). Narrative as Virtual Reality 2: Revisiting Immersion and Interactivity in Literature and Electronic Media. JHU Press.

Sims, N. (Ed.). (1984). The Literary Journalists (1st ed.). Ballantine Books.

Skloot, R. (2010). The Immortal Life of Henrietta Lacks. Crown Publishers.

Vaessens, T. (2011). Making overtures: Literature and journalism, 1968 and 2011: A Dutch perspective. Literary Journalism Studies 3(2), 55-72.

Weber, R. (1974). The Reporter as Artist: A Look at the New Journalism Controversy. Hastings House.

Weber, R. (1985). The Literature of Fact: Literary Non-Fiction in American Writing. Ohio University Press.

Wu, X., \& Gabrial, B. (2018). The Boundaries of Literary Journalism Scholarship: An Analysis of Literary Journalism Studies 2009-2017. Literary Journalism Studies 10(2), 39-57. 


\footnotetext{
(ㅇ) $(\mathbb{\theta} \Theta \Theta$ «Attibution - pas d'utilisation Commerciale - Pas de Modification 4.0. International» (CC BY-NC-ND)
} 